\title{
Transport of Sulphur Dioxide by Saccharomyces cerevisiae
}

\author{
By MALCOLM STRATFORD AND ANTHONY H. ROSE* \\ Zymology Laboratory, School of Biological Sciences, University of Bath, Bath, \\ Avon BA2 $7 A Y, U K$
}

(Received 9 August 1985)

\begin{abstract}
Accumulation of label from a suspension ( $\mathrm{pH} \mathrm{4.0)}$ ) of Saccharomyces cerevisiae containing $100 \mathrm{~mm}$-glucose and $1 \mathrm{~mm}-\left[{ }^{35} \mathrm{~S}\right]$ sulphite was initially rapid. Net accumulation ceased after $5 \mathrm{~min}$, but at this time $\left[{ }^{35} \mathrm{~S}\right]$ sulphite was still transported by organisms, and could be washed out to an extent that depended on the wash volume. Pre-incubation in the absence of glucose, and omitting glucose from the reaction mixture, had no effect on initial velocity of sulphite accumulation, although it decreased the total amount accumulated. Initial velocity of accumulation was also unchanged when organisms were pre-incubated in the presence of 2deoxy-D-glucose and this inhibitor was included in the reaction mixture. Initial velocity of sulphite accumulation decreased logarithmically as the $\mathrm{pH}$ value of the suspension was increased from 3.0 to 5.0 ; the decrease closely paralleled the decline in concentration of molecular $\mathrm{SO}_{2}$ over this $\mathrm{pH}$ range. Woolf-Hofstee plots for accumulation of $\mathrm{SO}_{2}$, at pH 3.0 or $4 \cdot 0$, gave near-vertical plots. Raising the temperature from 19 to $39^{\circ} \mathrm{C}$ increased the initial yelocity of $\mathrm{SO}_{2}$ accumulation. The initial velocity of transport was not affected by pretreatment of organisms with carbonyl cyanide $m$-chlorophenylhydrazone, DNP or iodoacetamide but pretreatment with $20 \mathrm{~mm}$-uranyl nitrate increased the initial velocity almost threefold. It is concluded that $\mathrm{SO}_{2}$ is transported into $S$. cerevisiae by simple diffusion.
\end{abstract}

\section{INTRODUCTION}

Sulphite in aqueous solution exists as a mixture of three forms, the proportions of which depend on $\mathrm{pH}$ value. At low $\mathrm{pH}$ values $\left(<1.77\right.$, the $\mathrm{pK}$ value of the equilibrium $\left.\mathrm{SO}_{2} \rightleftharpoons \mathrm{HSO}_{3}^{-}\right)$, sulphite exists predominantly as molecular $\mathrm{SO}_{2}$ and, at higher $\mathrm{pH}$ values $(>7 \cdot 20$, the $\mathrm{pK}$ value of the equilibrium $\left.\mathrm{HSO}_{3}^{-} \rightleftharpoons \mathrm{SO}_{3}^{2-}\right)$, largely as sulphite ions $\left(\mathrm{SO}_{3}^{2-}\right)$. At intermediate $\mathrm{pH}$ values, it exists in various proportions as the bisulphite ion $\left(\mathrm{HSO}_{3}^{-}\right.$; King et al., 1981). In this paper, the term 'sulphite' is used to denote collectively all three forms.

Very little has been reported on sulphite transport by micro-organisms; in some reports, the $\mathrm{pH}$ values used are not stated making it impossible to know the form in which sulphite was transported. In species of Aspergillus and Penicillium, separate specific transport systems for $\mathrm{SO}_{3}^{2-}$ and $\mathrm{SO}_{4}^{2-}$ were reported by Tweedie \& Segel (1970), while Alonso et al. (1984), working at $\mathrm{pH} 6 \cdot 1$, claimed that sulphite is transported into Candida utilis on the same system as $\mathrm{SO}_{4}^{2-}$ and $\mathrm{S}_{2} \mathrm{O}_{3}^{2-}$. The first report on sulphite transport into Saccharomyces cerevisiae came from Macris (1972) who concluded that, of the three forms of sulphite, only $\mathrm{SO}_{2}$ was transported. On the basis of the specificity and kinetics of, and the effect of temperature on, $\mathrm{SO}_{2}$ transport, Macris \& Markakis (1974) claimed that it was an active carrier-mediated process. The present paper reports further data on transport of $\mathrm{SO}_{2}$ into $S$. cerevisiae, and it arrives at a conclusion different from that of Macris \& Markakis (1974) concerning the mechanism of the process, and one which was suggested briefly by Stratford \& Rose (1985) and Hinze \& Holzer (1985).

Abbreviations: DOG, 2-deoxy-D-glucose; CCCP, carbonyl cyanide $m$-chlorophenylhydrazone. 


\section{METHODS}

Organism. The strain of $S$. cerevisiae used, TC8, was provided by T. Cowland of the Taunton Cider Co. It was maintained on slopes of malt extract/yeast extract/glucose/peptone/agar medium (Wickerham, 1951).

Experimental cultures. Cultures (1 litre) were grown in 2 litre round flat-bottomed flasks. The medium (pH 4.0 unless otherwise stated) had the following composition ( $\mathrm{l}^{-1}$ water): glucose $20 \mathrm{~g},\left(\mathrm{NH}_{4}\right)_{2} \mathrm{SO}_{4} 3 \mathrm{~g}, \mathrm{KH}_{2} \mathrm{PO}_{4} 3 \mathrm{~g}$, yeast extract ( $\mathrm{Lab} \mathrm{M}) 1 \mathrm{~g}, \mathrm{MgSO}_{4} .7 \mathrm{H}_{2} \mathrm{O} 30 \mathrm{mg}$ and $\mathrm{CaCl}_{2} .2 \mathrm{H}_{2} \mathrm{O} 30 \mathrm{mg}$ (Patching \& Rose, 1970). Starter cultures ( $100 \mathrm{ml}$ medium in a $250 \mathrm{ml}$ conical flask) were incoculated with a pinhead of yeast from a slant culture and incubated at $30^{\circ} \mathrm{C}$ for $12 \mathrm{~h}$ on an orbital shaker ( $200 \mathrm{r}$.p.m.). One litre portions of medium were inoculated with a portion of starter culture containing $1 \mathrm{mg}$ dry wt organisms, incubated at $30^{\circ} \mathrm{C}$ and stirred magnetically $(5 \mathrm{~cm}$ stirrer bar; 220 r.p.m.). Growth was followed by measuring optical density at $600 \mathrm{~nm}$, measurements being related to dry wt of yeast by a standard curve.

Measurement of initial velocities of solute accumulation. Organisms were harvested from late exponential-phase cultures $\left(0.5 \mathrm{mg}\right.$ dry $\left.\mathrm{wt} \mathrm{ml}^{-1}\right)$ by filtration through a membrane filter $(0.45 \mu \mathrm{m}$ pore size; $50 \mathrm{~mm}$ diam.; Oxoid), washed twice with $10 \mathrm{ml} 30 \mathrm{~mm}$-citrate buffer (pH 4.0 unless otherwise stated) containing $100 \mathrm{~mm}$-glucose, resuspended in $5 \mathrm{ml}$ of the same buffer and equilibrated at $30^{\circ} \mathrm{C}$ for $3 \mathrm{~min}$. The reaction mixture (15 ml) was citrate buffer ( $30 \mathrm{mM}$; $\mathrm{pH} 4.0$ unless otherwise indicated) containing $100 \mathrm{~mm}$-glucose, $5 \mu \mathrm{M}-5 \mathrm{~mm}$-sulphite and $\left[{ }^{35} \mathrm{~S}\right]$ sulphite $\left(0.05-0.20 \mu \mathrm{Ci} \mathrm{ml}{ }^{-1} ; 1 \mu \mathrm{Ci}=37 \mathrm{kBq}\right)$. This was placed in a $100 \mathrm{ml}$ round-bottomed flask, incubated at $30{ }^{\circ} \mathrm{C}$ unless otherwise indicated for $5 \mathrm{~min}$ and stirred magnetically $(1 \mathrm{~cm}$ stirrer bar; 200 r.p.m. $)$. The measurement was started by adding organisms in buffer containing $100 \mathrm{~mm}$-glucose to give a final concentration of $0.5-1.0 \mathrm{mg} \mathrm{dry} \mathrm{wt} \mathrm{ml-1}$. In certain experiments, organisms were pre-incubated for $1 \mathrm{~h}$ at $30^{\circ} \mathrm{C}$ in glucose-free buffer, with or without $100 \mathrm{~mm}-2$-deoxy-D-glucose (DOG). Initial velocities of accumulation by these organisms were measured in the same buffer. In other experiments, an examination was made of the effect of potential inhibitors on sulphite accumulation. These were included in the suspension of organisms in buffer which was incubated for $3 \mathrm{~min}$ at $30^{\circ} \mathrm{C}$ before a portion was taken to start the measurement of initial velocity. To do this, samples $(1 \mathrm{ml})$ were removed at intervals over a $10-35 \mathrm{~s}$ period, and rapidly filtered through membrane filters $(0.45 \mu \mathrm{m}$ pore size; $25 \mathrm{~mm}$ diam.; Millipore) the filters having been washed with $10 \mathrm{ml} 10 \mathrm{~mm}$-sulphite in $30 \mathrm{~mm}-$ citrate buffer at the $\mathrm{pH}$ value used in the experiment. After filtration, filters with organisms were rapidly washed with $5 \mathrm{ml}$ buffered sulphite solution at the concentration used in the experiment. Filters with organisms were placed in scintillation vials containing $7 \mathrm{ml}$ Optiphase 'Safe' (Fisons). Radioactivity in the vials was measured in a LKB Rackbeta liquid scintillation spectrometer (model 1217).

Initial velocities of accumulation of L-lysine were measured as described by Keenan et al. (1982). The suspension ( $15 \mathrm{ml}$ citrate buffer; $\mathrm{pH} 4.0$ ) contained organisms (1.0 mg dry wt $\left.\mathrm{ml}^{-1}\right), 100 \mu \mathrm{M}-\mathrm{L}-\mathrm{lysine}$ $\left(1.0 \mu \mathrm{Ci} \mu \mathrm{mol}^{-1}\right)$ and unless otherwise stated $100 \mathrm{~mm}$-glucose. The suspension was incubated at $30^{\circ} \mathrm{C}$, the experiment started by adding solute (tracer and carrier) and the velocity of accumulation measured over the first $2 \mathrm{~min}$.

Measurement of equilibrium fluxes. Organisms $\left(1.0 \mathrm{mg}\right.$ dry wt $\left.\mathrm{ml}^{-1}\right)$ in $30 \mathrm{~mm}$-citrate buffer $(15 \mathrm{ml} ; \mathrm{pH} 4.0)$ containing glucose $(100 \mathrm{~mm})$ and $1 \mathrm{~mm}-\left[{ }^{35} \mathrm{~S}\right]$ sulphite were allowed to accumulate label for $5 \mathrm{~min}$. After this time, efflux of label from organisms was measured by removing five portions $(1 \mathrm{ml})$ of suspension, and filtering each through a membrane filter as already described. Organisms on filters were washed with different volumes (1$100 \mathrm{ml}$ ) of $30 \mathrm{~mm}$-citrate buffer containing, except when otherwise stated, $1 \mathrm{~mm}$-sulphite. The times taken to complete the washings were noted, and the radioactivity of organisms recorded for that time. Influx of label into organisms, after net accumulation had ceased $(5 \mathrm{~min})$, was measured by adding $\left[{ }^{35}\right.$ S]sulphite $(5 \mu \mathrm{M}$; $\left.80 \mu \mathrm{Ci} \mathrm{mmol}^{-1}\right)$ to a suspension $\left(1.0 \mathrm{mg} \mathrm{dry} \mathrm{wt} \mathrm{ml} \mathrm{m}^{-1}\right)$ in $15 \mathrm{ml}$ buffer containing unlabelled sulphite $(1 \mathrm{mM})$ and glucose $(100 \mathrm{~mm})$. Accumulation of label by organisms was measured over the following $2 \mathrm{~min}$.

Chemicals. All chemicals used were Analar or of the highest grade available commercially. Amersham supplied sodium $\left[{ }^{35} \mathrm{~S}\right]$ sulphite which was stored at $-20^{\circ} \mathrm{C}$ in 5 mM-EDTA to avoid oxidation.

\section{RESULTS}

\section{Kinetics of sulphite accumulation}

Accumulation of ${ }^{35} \mathrm{~S}$-label from a suspension containing $\left[{ }^{35} \mathrm{~S}\right]$ sulphite was rapid over the first minute, after which the velocity declined (Fig. 1). Net accumulation ceased after approximately $5 \mathrm{~min}$. Organisms incubated in buffer containing unlabelled sulphite for $5 \mathrm{~min}$ were able to incorporate added $\left.{ }^{35} \mathrm{~S}\right]$ sulphite at a velocity similar to that observed over the first minute in suspensions containing [ $\left.{ }^{35} \mathrm{~S}\right]$ sulphite. It was also possible to wash label out of organisms after 5 min incubation, to an extent which depended on the volume of buffer used for washing (Fig. 1). The velocity of efflux did not change when organisms were washed with sulphite-free buffer. Woolf-Hofstee plots (Hofstee, 1959) for accumulation of $\mathrm{SO}_{2}$ by organisms, at $\mathrm{pH} 3.0$ or 4.0, 

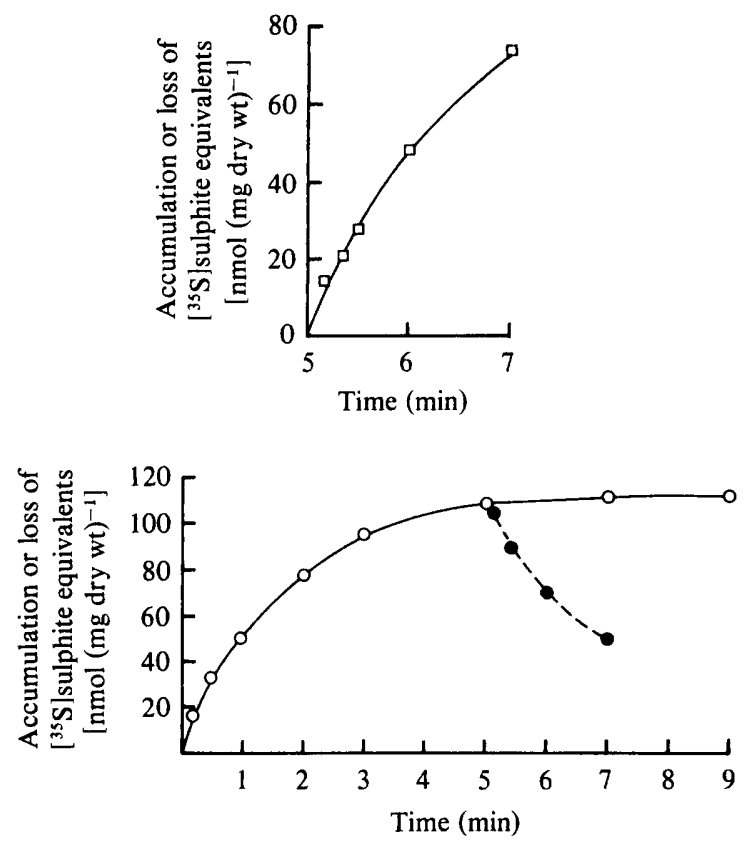

Fig. 1

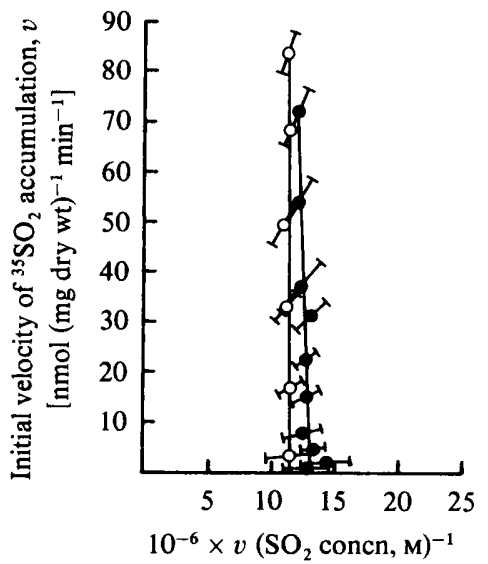

Fig. 2

Fig. 1. O, Time-course of accumulation of sulphite equivalents by $S$. cerevisiae TC8 $(1.0 \mathrm{mg}$ dry wt $\mathrm{ml}^{-1}$ ) from $30 \mathrm{~mm}$-citrate buffer $(\mathrm{pH} \mathrm{4.0})$ containing glucose $(100 \mathrm{mM})$ and $\left[{ }^{35} \mathrm{~S}\right]$ sulphite $(1 \mathrm{mM}) ; \mathbf{O}$, time-course of efflux of sulphite equivalents from organisms harvested after $5 \mathrm{~min}$ and washed on filters with different volumes of buffer, as described in Methods; $\square$, accumulation of sulphite equivalents by organisms initially incubated in a suspension containing unlabelled sulphite for $5 \mathrm{~min}$ and then supplemented with ${ }^{35}$ S]sulphite, as described in Methods. Data shown are representative of those obtained in three separate experiments.

Fig. 2. Woolf-Hofstee plots for accumulation of molecular $\mathrm{SO}_{2}$ by $S$. cerevisiae TC8 suspended in buffer at $\mathrm{pH} 3.0(\mathrm{O})$ or $\mathrm{pH} 4.0(\mathrm{O})$. Concentrations of molecular $\mathrm{SO}_{2}$ at the different $\mathrm{pH}$ values were calculated from the data of King et al. (1981). Bars indicate SD.

Table 1. Effect of glucose and DOG on initial velocities of accumulation of $\mathrm{SO}_{2}$ and L-lysine by

\section{Saccharomyces cerevisiae TC8}

Organisms were suspended in supplemented or unsupplemented citrate buffer ( $\mathrm{pH} \mathrm{4.0)}$ for $1 \mathrm{~h}$ before initial velocities were measured over the first $10 \mathrm{~s}$. The reaction mixture also contained the supplement at the concentration stated. Values quoted are means of at least three separate measurements $\pm \mathrm{SE}$.

\begin{tabular}{|c|c|c|}
\hline & \multicolumn{2}{|c|}{$\begin{array}{l}\text { Initial velocity (percentage of initial } \\
\text { velocity in a glucose-containing } \\
\text { suspension) }\end{array}$} \\
\hline Supplement & $\begin{array}{c}\mathrm{SO}_{2} \\
(5.8 \mu \mathrm{M})\end{array}$ & $\begin{array}{l}\text { L-Lysine } \\
(0.1 \mathrm{mM})\end{array}$ \\
\hline Glucose (100 mM) & $100.0 \pm 7.9$ & $100.0 \pm 3.6$ \\
\hline None & $95.5 \pm 12.1$ & $9.8 \pm 0.7$ \\
\hline DOG (100 mM) & $100 \cdot 2 \pm 13.7$ & $5.3 \pm 0.8$ \\
\hline
\end{tabular}

gave near vertical plots (Fig. 2). Pre-incubating organisms in glucose-free buffer and omitting glucose from the reaction mixture had no effect on initial velocities of $\mathrm{SO}_{2}$ accumulation, measured at $2 \mathrm{~s}$ intervals over the first $10 \mathrm{~s}$. It did, however, approximately halve the amount accumulated after $5 \mathrm{~min}$. Pre-incubating organisms in the presence of DOG (100 mM), and including this inhibitor in the reaction mixture at the same concentration, also had no effect on initial velocities of $\mathrm{SO}_{2}$ accumulation (Table 1). 


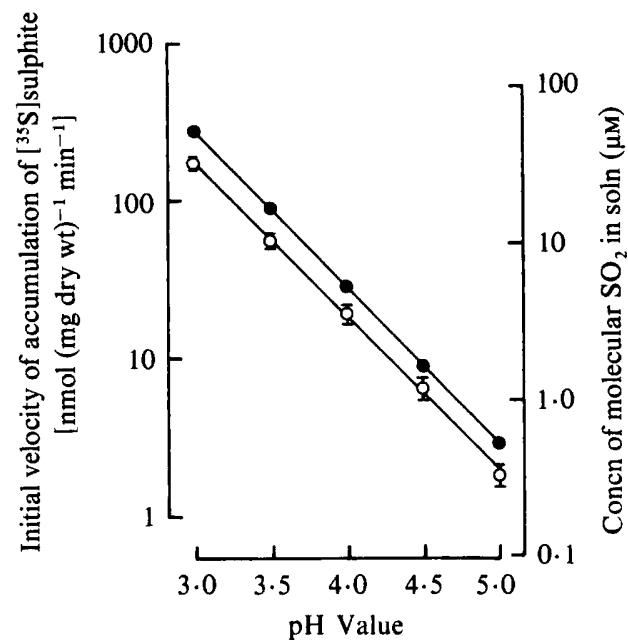

Fig. 3

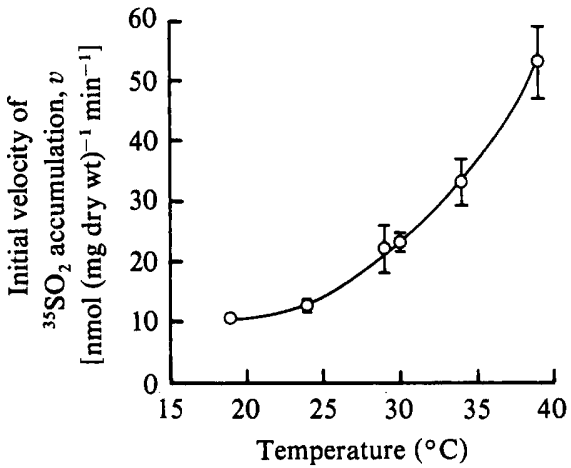

Fig. 4

Fig. 3. Effect of $\mathrm{pH}$ value on initial velocities of accumulation of $\left[{ }^{35} S\right]$ sulphite equivalents by $S$. cerevisiae TC8 suspended in buffer containing $100 \mathrm{mM}$-glucose and $0.5 \mathrm{mM}-\left[{ }^{35} \mathrm{~S}\right]$ sulphite $(O)$ and on the concentration of molecular $\mathrm{SO}_{2}$ in the suspensions (O) calculated from the data of $\mathrm{King}$ et al. (1981). Bars indicate SD.

Fig. 4. Effect of temperature on initial velocities of accumulation of $\mathrm{SO}_{2}$ by $S$. cerevisiae TC8 suspended in buffer containing $100 \mathrm{mM}$-glucose and $1.77 \mu \mathrm{M}-\mathrm{SO}_{2}$. Bars indicate SD.

Table 2. Effect of inhibitors on initial velocities of accumulation of $\mathrm{SO}_{2}$ and L-lysine by Saccharomyces cerevisiae TC8

Initial velocities were measured over the first $10 \mathrm{~s}$. Values quoted are means of at least three separate measurements \pm SE.

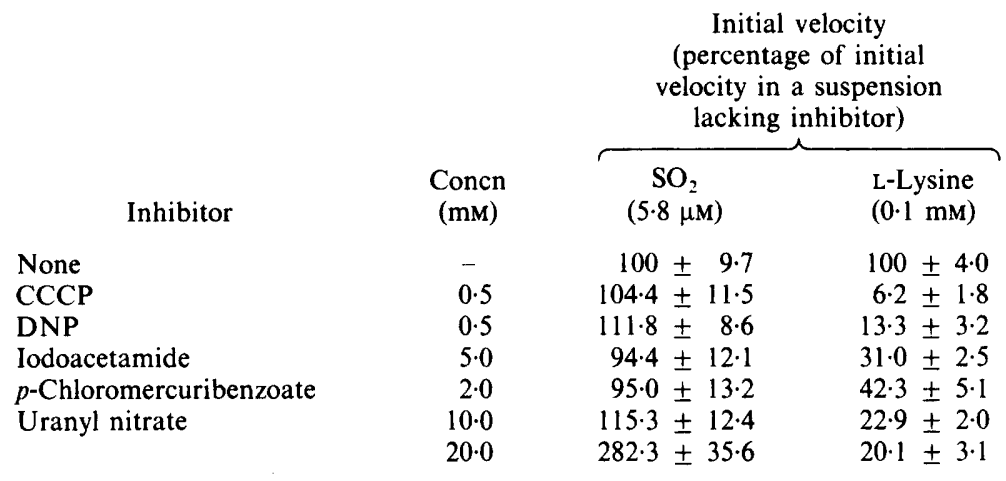

\section{Factors affecting accumulation of sulphite}

The initial velocity of sulphite accumulation decreased logarithmically as the $\mathrm{pH}$ value of the suspension was increased from 3.0 to 50 (Fig. 3). This decrease closely paralleled the decline in concentration of molecular $\mathrm{SO}_{2}$ as the $\mathrm{pH}$ value was increased over this range as calculated from the data of King et al. (1981). There was no evidence for loss of $\mathrm{SO}_{2}$ from solutions in this $\mathrm{pH}$ range over the time scale of these experiments. Raising the temperature of the suspension from $19^{\circ} \mathrm{C}$ to $39^{\circ} \mathrm{C}$ increased the initial velocity of $\mathrm{SO}_{2}$ accumulation by organisms (Fig. 4). Over the range $19-39^{\circ} \mathrm{C}$, the $Q_{10}$ value was 2.5 . When potential inhibitors were included in cell suspensions, none except uranyl nitrate at $20 \mathrm{mM}$ had a significant effect on the initial velocity of transport of $\mathrm{SO}_{2}$ present at $5.8 \mu \mathrm{M}$ (Table 2). When the inhibitors were included in suspensions 
of organisms at the same concentrations, DNP and CCCP almost completely prevented accumulation of L-lysine, while accumulation of the amino acid was considerably retarded by iodoacetamide, $p$-chloromercuribenzoate and uranyl nitrate (Table 2).

\section{DISCUSSION}

The close correlation between the rate of accumulation of label from $\left[{ }^{35} S\right]$ sulphite by organisms, over the $\mathrm{pH}$ range $3 \cdot 0-5 \cdot 0$, and the concentration of $\mathrm{SO}_{2}$ in solution calculated from the data of King et al. (1981), strongly suggests that, over this $\mathrm{pH}$ range, the only form that passes into organisms is $\mathrm{SO}_{2}$. This conclusion, and the inference that $S$. cerevisiae does not transport $\mathrm{HSO}_{3}^{-}$, are in agreement with Macris \& Markakis (1974) and Hinze \& Holzer (1985).

However, we do not agree with Macris \& Markakis (1974) with regard to the manner in which $\mathrm{SO}_{2}$ passes into organisms, and we suggest that our data lead to the conclusion that $\mathrm{SO}_{2}$ is transported into $S$. cerevisiae by simple diffusion. Strong evidence in favour of a protein not being involved in $\mathrm{SO}_{2}$ transport came from the near-vertical Woolf-Hofstee plots for transport at $\mathrm{pH} 3.0$ and $4 \cdot 0$. Neither plot is perfectly vertical, so that kinetic constants could be derived from them $\left[\mathrm{pH} 4.0 ; K_{\mathrm{T}} 0.11 \mathrm{mM}, V_{\max } 1.4 \mu \mathrm{mol}\left(\mathrm{mg}\right.\right.$ dry wt) ${ }^{-1} \mathrm{~min}^{-1}: \mathrm{pH} 3.0 ; K_{\mathrm{T}} 3.2 \mathrm{mM}, V_{\max }$ $1.4 \mu \mathrm{mol}\left(\mathrm{mg}\right.$ dry wt) ${ }^{-1} \mathrm{~min}^{-1}$ ]. These $K_{\mathrm{T}}$ values are considerably greater than the threshold concentration of $\mathrm{SO}_{2}$ required to kill $S$. cerevisiae TC8 under these conditions (Stratford, 1983). Deviation from the vertical for the Woolf-Hofstee plot for accumulation at $\mathrm{pH} 4.0$ is caused very largely by data points at low concentrations of $\mathrm{SO}_{2}$. This might suggest that, as the concentration of $\mathrm{HSO}_{3}^{-}$increased when the $\mathrm{pH}$ value was raised, a slow transport system for this ion which was probably saturated may have been functioning, activity of which was masked in the presence of higher concentrations of $\mathrm{SO}_{2}$. Additional evidence for lack of involvement of proteins came from the inability of iodoacetamide and $p$-chloromercuribenzoate to affect the initial velocity of transport. The absence of active transport during entry of $\mathrm{SO}_{2}$ into organisms is suggested by the inability of CCCP and DNP (Borst-Pauwels, 1981) to affect the initial velocity. The effect of CCCP and DNP on accumulation of L-lysine indicated that they were used at concentrations that almost completely inhibit active transport of the amino acid. The ability of uranyl nitrate, at $20 \mathrm{~mm}$ but not $10 \mathrm{mM}$, to increase the initial velocity of $\mathrm{SO}_{2}$ accumulation is probably explained by its causing an increase in the permeability of the yeast plasma membrane after the large uranyl ions react with phospholipid polar headgroups. A concentration-dependent inhibition of yeast transport systems by uranyl nitrate has been reported by Maxwell et al. (1970). Further evidence for lack of active transport of $\mathrm{SO}_{2}$ came from the finding that, although glucose was included in the reaction mixture because Macris \& Markakis (1974) claimed that $\mathrm{SO}_{2}$ accumulation is an active process, excluding the sugar from reaction mixtures had no effect on initial velocities of accumulation. The ability of glucose to increase the extent of accumulation is probably explained by the maintenance of a relatively high internal pH value as a result of glycolysis (Conway \& Downey, 1950). The inability of DOG to affect initial velocities of $\mathrm{SO}_{2}$ accumulation also argues against the process being an active one. A $Q_{10}$ value of 2.5 over the temperature range $19-39^{\circ} \mathrm{C}$ is somewhat higher than values usually encountered with diffusion processes (Stein, 1967), although the absence of an overall decline in the rate of $\mathrm{SO}_{2}$ transport up to a temperature of $39^{\circ} \mathrm{C}$ might be taken as evidence for no protein involvement. Unlike Macris \& Markakis (1974) it was considered injudicious to examine transport at temperatures higher than $39^{\circ} \mathrm{C}$ because of the possibility of causing cell death. Additional evidence for a lack of protein involvement in $\mathrm{SO}_{2}$ transport is provided by the absence of an effect of $\mathrm{pH}$ value on the process other than that predicted by changes in substrate concentration.

The time-course of accumulation of label from ${ }^{35} \mathrm{SO}_{2}$ requires a more detailed explanation. Accumulation of label in organisms was initially very rapid, but levelled off after about $5 \mathrm{~min}$ when the concentration of label in organisms, assuming a water content of $2 \mu \mathrm{l}(\mathrm{mg} \text { dry wt) })^{-1}$ (Beavan et al., 1982), was approximately 60 times that in the suspension. Accumulation of label from $\mathrm{SO}_{2}$ under these conditions can be explained by combination of sulphite with intracellular carbonyl-containing compounds to produce $\alpha$-hydroxysulphonates (Burroughs \& Sparks, 1964) 
and by the greater intracellular (about $\mathrm{pH} 6 \cdot 5$ ), compared with extracellular, $\mathrm{pH}$ value (BorstPauwels, 1981). From the latter consideration, it is inferred that free $\mathrm{SO}_{2}$ after diffusion into organisms is largely converted into $\mathrm{HSO}_{3}^{-}$ions. This in turn lowers the intracellular concentration of $\mathrm{SO}_{2}$ thus allowing further diffusion into organisms until the concentration of $\mathrm{SO}_{2}$ is equal on both sides of the plasma membrane. This explanation is supported by the equilibrium fluxes that were demonstrated in suspensions of organisms that had accumulated $\mathrm{SO}_{2}$ for up to $5 \mathrm{~min}$.

Our disagreement with the conclusion by Macris \& Markakis (1974) as to the manner of transport of $\mathrm{SO}_{2}$ requires justification. Many of the findings reported by these workers, especially the time-course of $\mathrm{SO}_{2}$ accumulation and the results of double-reciprocal plots, are similar to those reported herein. However, additional evidence reported in the present paper leads us to conclude that $\mathrm{SO}_{2}$ transport into $S$. cerevisiae is not an active process (Macris \& Markakis, 1974) but is by simple diffusion.

We thank the Science and Engineering Research Council for the award of a CASE studentship to M.S. in collaboration with The Taunton Cider Co. Ltd, Norton Fitzwarren, Somerset. Our gratitude also goes to Jill Calderbank for critical appraisal of the manuscript, and to Felicity Veazey for timely technical assistance.

\section{REFERENCES}

Alonso, A., Benitez, J. \& Diaz, M. A. (1984) A sulfate, sulfite and thiosulphate incorporating system in Candida utilis. Folia microbiologica 29, 8-13.

Beavan, M. J., Charpentier, C. \& Rose, A. H. (1982). Production and tolerance of ethanol in relation to phospholipid fatty-acyl composition in Saccharomyces cerevisiae NCYC 431. Journal of General Microbiology 128, 1447-1455.

Borst-PauWels, G. W. F. H. (1981). Ion transport in yeast. Biochimica et biophysica acta 650, 88-127.

Burroughs, L. F. \& SPARKS, A. H. (1964). The identification of sulphur dioxide-binding compounds in apple juices and ciders. Journal of the Science of Food and Agriculture 15, 176-185.

Conway, E. J. \& DownEY, M. (1950). pH Values of the yeast cell. Biochemical Journal 47, 355-360.

Hinze, H. \& Holzer, H. (1985). Accumulation of nitrite and sulphite in yeast cells and synergistic depletion of the intracellular ATP content. Zeitschrift für Lebensmittel Untersuchung und Forschung 180, 117-120.

HOFSTEE, B. H. J. (1959). Non-inverted versus inverted plots in enzyme kinetics. Nature, London 184, 1296 1298.

Keenan, M. H. J., Rose, A. H. \& Silverman, B. W. (1982). Effect of plasma-membrane phospholipid unsaturation on solute transport into Saccharomyces cerevisiae NCYC 366. Journal of General Microbiology 128, 2547-2556.

King, A. D. JR, Ponting, J. D., Sanshuck, D. W., JACKSON, R. \& MIHARA, K. (1981). Factors affecting death of yeast by sulphur dioxide. Journal of Food Protection 44, 92-97.
MACRIS, B. J. (1972). Transport and toxicity of sulfur dioxide in the yeast Saccharomyces cerevisiae var. ellipsoideus. PhD thesis, Michigan State University, USA.

MACRIS, B. J. \& MARKaKIS, P. (1974). Transport and toxicity of sulfur dioxide in Saccharomyces cerevisiae var. ellipsoideus. Journal of the Science of Food and Agriculture 25, 21-29.

MaXwell, W. A., Metzler, R. \& Spoerl, E. (1970). Uranyl nitrate inhibition of transport systems in Saccharomyces cerevisiae. Journal of Bacteriology 105, 1205-1206.

Patching, J. W. \& Rose, A. H. (1970). The effect and control of temperature. Methods in Microbiology 2, 23-38.

STEIN, W. D. (1967). The Movement of Molecules Across Cell Membranes. London: Academic Press.

STRATFORD, M. (1983). Sulphite metabolism and toxicity in Saccharomyces cerevisiae and Saccharomycoides ludwigii. PhD thesis, University of Bath, UK.

StratFord, M. \& Rose, A. H. (1985). Hydrogen sulphide production from sulphite by Saccharomyces cerevisiae. Journal of General Microbiology 131, $1417-1424$

Tweedie, J. W. \& Segel, I. H. (1970). Specificity of transport processes for sulfur, selenium and molybdenum anions by filamentous fungi. Biochimica et biophysica acta 196, 95-106.

WICKerhaM, L. J. (1951). Taxonomy of yeasts. I. Techniques of classification. United States Department of Agriculture Technical Bulletin, no. 1029. Washington, DC: US Department of Agriculture. 